\title{
Peeling onions with Granny: on being moved to collaborate
}

Article

Accepted Version

Murjas, T. (2019) Peeling onions with Granny: on being moved to collaborate. Performing Ethos, 9 (1). pp. 37-53. ISSN 17571987 doi: https://doi.org/10.1386/peet_00004_1 Available at https://centaur.reading.ac.uk/82870/

It is advisable to refer to the publisher's version if you intend to cite from the work. See Guidance on citing.

Published version at: https://www.ingentaconnect.com/contentone/intellect/peet/2019/00000009/00000001/art00004 To link to this article DOI: http://dx.doi.org/10.1386/peet_00004_1

Publisher: Intellect

All outputs in CentAUR are protected by Intellectual Property Rights law, including copyright law. Copyright and IPR is retained by the creators or other copyright holders. Terms and conditions for use of this material are defined in the End User Agreement.

\section{www.reading.ac.uk/centaur}

\section{CentAUR}

Central Archive at the University of Reading

Reading's research outputs online 
TERESA MURJAS

University of Reading, UK

\title{
Peeling Onions with Granny: On Being Moved to Collaborate
}

\begin{abstract}
This article contemplates the work of UK-based artists' collective Peeling Onions with Granny (POWG). It explores the synergies between four mixed-media projects. These centre on intergenerational legacies of forced displacement. Each artist discussed was born in the UK in the 1960s/70s. However, during or shortly after the Second World War, our parents and/or grandparents fell victim to Soviet mass deportations from Poland and Latvia to Siberia. The article reflects on the ethical dimensions of our creative engagement with these legacies. It asks what, in a politically volatile 'pre-Brexit' climate, we as both practitioners and descendants of immigrants are bringing to the 'feast'.
\end{abstract}

KEYWORDS

Forced displacement; Inter-generational legacies; Personal archives.

A Taste of Home (January, 2019)

Sajid Javid's rhetoric on refugees has less to do with reason than with appeasing anti-immigrant feeling (Hirsch 2019: n.pag.)

Last year, my 83-year old mother sustained a life-threatening injury, causing her extreme physical and mental distress. Over Christmas I cared for her in her Derby home. Each day, she follows the radio news. Last night, we heard reports of the Home Secretary's request to the Royal Navy to patrol the English Channel and intercept vessels bearing migrants. 'I crossed the channel too,' reminded my mother, referencing her 1948 arrival in the United Kingdom as a Polish refugee, 'only that was on a ship, not a dinghy'. 


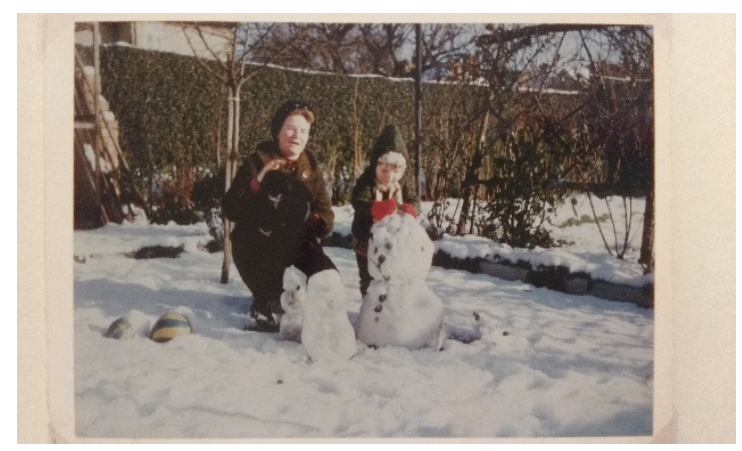

Figure 1: A family photograph of me with my mother, Irena, in our garden in Derby, United Kingdom, in the early 1970s. Copyright: Teresa Murjas

A few minutes earlier, in fear, she had been trying to phone me on her landline, though I sleep in the adjacent room. Convinced that the NKVD - or Soviet coercive apparatus - had deported me, she wanted to find out if they would be willing to take her along, so we could stay together. In 1940 the NKVD deported her family from South-Eastern Poland to Siberia; she was just under five years old.

Yet by far the largest tide [of humanity in motion] started to flow [...] out of Soviet occupied eastern Poland, whence, under the auspices of Stalin's security services, between one and two million people were deported to distant parts of the USSR, the largest country on Earth (Davies 2015: 17)

Jump forward to 1948, and my mother, aunt and grandmother arrived in Southampton aboard the good ship Carnarvon Castle following six years in a British-run refugee camp in Bwana MKubwa, a town in Zambia's Copperbelt Province which at that time was located in Northern Rhodesia. Next stop: a displaced persons' camp near Market Harborough. Wiping her eyes, my mother instructed me to turn off the radio. 'Bloody Brexit, bloody mess,' she said. Then she turned to the wall and went to sleep.

'Deportation' is a word with an overwhelming emotional charge; whole families, mothers, children, elderly people fell victim to deportations, and the truth about them was suppressed for years (Bikont 2015: 59)

I couldn't sleep, states of (hyper) vigilance are familiar to members of Marianne Hirsch's 'next generations'. My mother is no longer a refugee, a title she once embraced. She is a naturalized British citizen. Yet, here we were in her bedroom, faced with another 'refugee crisis'. 


\section{Introduction: on producing more archive}

The archivist produces more archive, and that is why the archive is never closed. It opens out of the future (Derrida 1996: 68)

In this article I present four projects that explore inter-generational legacies of forced displacement, created by artists from the Peeling Onions with Granny collective (POWG). In the context of Anika Marschall's question, what can theatre do - what has arts practice been doing - about the refugee crisis (Marschall 2018: 148), and Will Daddario et al's call to develop appropriate art-philosophical responses to it (Daddario et al. 2018: 207), I consider what these projects offer at a time when 'the circulation of visual material produced in and through processes of artistic collaboration between refugees and hosts is especially vital' (Cox and Wake 2019: 147).

POWG are still in the early stages of collaboration. However, they rapidly identified a shared emphasis on engagement with family archives. In order to produce narrational anchorage, all four projects discussed here 'rest' on family archives shaped by forced displacement. In addition, each project stages a 'next generation' encounter with relevant archival materials, and thus reconfigures the archive's boundaries. This article considers how each projects' formal and aesthetic properties emerge through this process. Additionally, it speculates whether the synchronous 'opening out' of these archives can generate a collaboratively held ethical position.

POWG formed in 2016, around the time of the EU referendum. The founding artists have strong connections with the forced displacement context outlined above. The fathers of Colchester-based artist/performer Chris Dobrowolski and Coventry-based sound-artist Adrian Palka were both deported from Poland to Siberia and arrived in the UK after the Second World War, whereas the paternal family of London-based artist/film-maker Simon Puriņš hails from Latvia, and it is from there that his grandmother was also deported to Siberia, whereas his father settled in the UK after the war. Only two POWG practitioners (Palka and myself) are academics. POWG arose from the desire to respond, through collaboration, to the sociopolitical debate and decision-making concerning refugees, and to anti-immigrant discourses and those that counter them, emerging in the context and aftermath of the EU referendum. We have stories of migration to tell, our ability to tell them is strengthening, working together is empowering. Accordingly, in December 2016, four POWG artists showed thematically complementary work at the University of Reading and in April 2018, for the Essex Book 
Festival, five artists presented adapted work in site-responsive forms at Kelvedon Hatch Nuclear Bunker. Today, POWG encompasses twelve artists, including colleagues recently settled in the United Kingdom. Its diversification and collaborations continue, including a project with Essex Book Festival 2020 that first emerged as a workshop for Tate Exchange, London in 2019. The projects considered here range across media, including live performance, installation, and filmmaking. Holding experiences of forced displacement at their core, they emphasise trans-generational, transpersonal themes. Through its mediation of personal archives, each project evokes voices of forcibly displaced individuals. In the context of state reluctance to open archives relating to the Soviet deportations, our emphasis on personal resources and associated acts of oral storytelling carries political significance. ${ }^{1}$ In all four projects discussed here, the displaced person is/was a parent/grandparent of the artist. In all four, the practitioners, or their children, participate in the work, acting as both witnesses and subjects. Movements between, or the overlaying of, these roles can here be construed as acts of empathy, a complex proposition given the frequently traumatic nature of experiences held by these personal archives. Reaching an understanding is less straightforward, perhaps, than simply reaching for the archive.

Reflections on my colleagues' work co-exist with exposition of my own practice. Thus, in the context of trauma studies, honouring Hirsch's writings on post-memory (Hirsch 2012) and Wake's analysis of the relational/spectatorial dimensions of performance (Wake 2013), I allow autobiographical material to assume a role in my discussion of a project created with my mother, Surviving Objects, first shown in 2013. I believe it reveals how ethical and aesthetic considerations arise in those interstices that lie between my roles as daughter, practitioner and academic. It is through their navigation that a lifetime's dialogue with Irena about her deportation/re-integration has found its performative expression. Here, through my evocation of her presence, I seek to mirror the project's purpose.

Surviving Objects explores how a specific individual's privately 'held' experience of forced migration, and her subsequent recuperation, might be publicly communicated through creative practice, simultaneously foregrounding the contemporary second-generation

\footnotetext{
${ }^{1}$ Following the collapse of the Soviet Union in 1991 after the end of the Cold War, many formerly closed and classified Soviet State archives started to become at least partially available to researchers for the first time, including those relating to the Gulag or Soviet forced labour camp system. The process of enabling transparency has not been straightforward or uniform in countries that were part of or annexed by the Soviet Union, or in the Soviet Bloc. More recently, there have been suggestions of a move towards the so-called resecretisation of Soviet state archives, particularly accompanying Russia's 'rehabilitation of Stalin' (see for example https://www.theguardian.com/commentisfree/2019/jul/10/vladimir-putin-russia-rehabilitatingstalin-soviet-past)
} 
practitioner's role. Such practitioners can act as explainers, translators, intermediaries, interpreters, mediators, custodians, verifiers or indeed, sceptics and resistors, walking the line between empathy and activism in their work. Reactions and dialogue stimulated within the current political climate by any exposition of these intimate narratives, especially - though not only - outside those diasporically focused venues in the United Kingdom whose cultural life has itself been transformed on account of migration over the last twenty years or so, are of great interest to POWG. When I in turn reflect on my colleagues' work, my perspective must invariably be realigned with that of the audience/ participant. Here, I take courage from Daddario et al's assertion that 'affective jolts' can move productively within an academic frame.

If [the] notion and hierarchy of the giver and receiver roles can be interchanged or seen as shifting and reciprocating regularly, the refugee could become the giver sometimes, for example in some cultural aspects such as contributing to the food/cuisine of a place. However, for this too, the "host" needs to be able to shift his/her role (or the host country its role) and be able to receive. This would entail, not to discard everything brought in and offered by the refugees as a blanket rule (Daddario et al. 2018: 209)

In Günter Grass's late work, peeling an onion is a metaphor for attempts to bring to consciousness, in old age, what one considers savoury, and also un-savoury, about one's past (Grass 2006). In Ibsen's late work, digging up and peeling wild onions by hand is a metaphor for perceiving manifold 'morally pungent' iterations of one's self (Ibsen 1867). In the Tale of Ragnar Lothbrok, eating a wild onion is a metaphor for both survival strategy and compromise in the face of unreasonable external demands (Crawford 2017). For Carol-Ann Duffy, the onion is a metaphor for love (Duffy 1993), and for Suji Kwock Kim a tangible means of painful inner transformation (Kwock Kim 2003). For POWG, each association resonates, a photograph of Puriņš’s grandmother Marija inspired our name. Deploying wit in dangerous circumstances, rather like Aslaug, she secured early release from Siberian exile in 1947. 


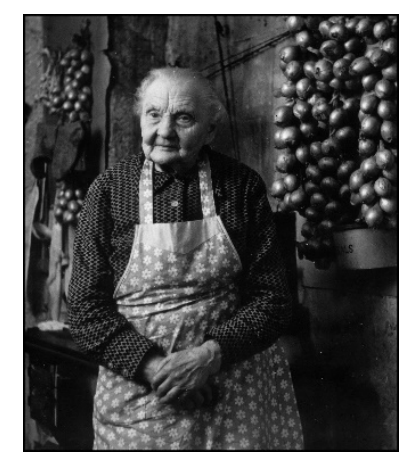

Figure 2: A family photograph of Marija Puriņš by Andrejs Feldmanis, date unknown. Copyrightt: Andrejs Feldmanis.

Our name proposes collaboration as a mode of action - this perhaps is what be-aproned Marija awaits. It also emphasises the sensory dimensions of essential labour. The healing potential, for those who have experienced human rights abuses, of sharing (creative) labour is well documented, especially in relation to participatory arts and art therapy (O’Neill 2008; Akthar and Lovell 2018). Catherine Orbach, Martha Orbach and Mary Raphaely explore it through their work with plants and in gardens, at London's Room to Heal, a charity supporting people who have survived torture and organised violence, as do members of Küche, in Glasgow, particularly when working with migrant communities and food. ${ }^{2}$ In addition, the significance of objects and their tangibility as grounding devices for communicating stories of migration has been explored through such recent performances as London Stories at the Battersea Arts Centre (2013) and Room to Breathe, an exhibition/installation at London's Migration Museum (2018-19).

For us, peeling onions is also a metaphor for working creatively with personal archives: a sensory experience, bursting with emotional 'bite'. Below I explain how, through animating archives, we perform legacies of forced displacement, often incorporating acts of translation and aesthetics of temporal layering. We show work collaboratively in order to enable the conceptualization of our society as a place where migrants and their descendants can be regarded as integral, and, indeed, as welcoming hosts; where, through their creative labour, the possibility is increased of 'building an image of the refugee', of the migrant, 'as someone who carries richness within him/herself and can' - and does - 'thereby offer possibilities to the new' (and/or old) 'land/country' (Daddario et al. 2018: 209). This can serve as a possible mode of action - albeit constrained - to counter anti-immigrant rhetoric in our current political climate.

\footnotetext{
${ }^{2}$ See https://www.kueche.co.uk/
} 


\section{Surviving Objects}

The transpersonal is a zone of relation that is social, affective, material, and inevitably public (Hirsch and Miller 2011: 5)

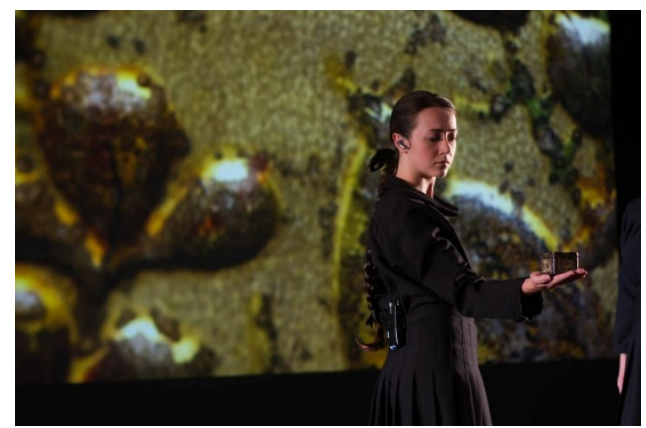

Figure 3: Object handler, played by Rosie Whatley, holding a tin from Uzbekistan. Macro-lens footage of its surface is projected behind her. Surviving Objects (2014). Photograph by Robbie McKane. Copyright: Teresa Murjas.

Surviving Objects is an ongoing creative project through which my mother Irena and I reengage with our receding memories of her forced displacement during and after the Second World War. Narratively, in adherence to her decision, it focuses particularly on the six years that Irena spent in a refugee camp in Africa. It does so by drawing on a series of objects, including a small selection of photographs, from a personal archive associated with that time in her life, and on conversations we recorded over several months which centred on these materials.

This heuristic investigation into how privately held stories of forced displacement might be told publicly, has had four iterations (2013, 2014, 2016 and 2018). I use the term heuristic in relation to this practice-led research because I would like to signal how significant ideas of tentative discovery and abject failure have been, both to the dialogue that has underpinned it and to its iterative, collaborative evolution. The project is far from optimal, perfect or entirely rational; it is sufficient and has been characterized increasingly by loss. A staged exhibition, it incorporates objects from Irena's small personal archive consolidated in Bwana MKubwa refugee camp and audio-recorded stories handed down with them, which I recorded and edited. Initially, in the first two iterations $(2013,2014)$ these performance elements co-existed with the live-presence of two object-handlers and large-scale projection of macro-lens footage showing partial object-surfaces and textures, aimed at enhancing sensations 
of tangibility and evoking temporal layering. The third iteration (2016) removed the objecthandlers to focus on the other elements, with objects placed on plinths rather than the floor. The fourth iteration (2018) re-created a version of my mother's current living room (complete with plants) in a nuclear bunker, where visitors encountered objects as though in their 'original' location, and the digital material on ipads, with headphones.

A tin from Uzbekistan, an embroidered handkerchief, a child's school-case, buttons, a material swatch, two wooden animal sculptures and Polish school text books from Bwana MKubwa, in former Northern Rhodesia (currently in Zambia); a wedding ring from the Belgian Congo (currently the Democratic Republic of Congo). These objects had always appeared enmeshed in my mother's oft-repeated provenance stories, striking tales characterised by variations on the same phrases and narrative formulations. Irena progressively refined her storytelling method throughout her life so that, for me, a captive listener, particular thematic strands gradually assumed the apparent inviolability of things learned by rote. She had always made editorial choices, and these were perhaps enhanced by her awareness of the stories' impending public airing: Surviving Objects (2013). I recorded her in several settings whose traces remain perceptible; birdsong, traffic, passing aircraft, a ticking clock, clinking teaspoons. Our dialogue, which took place in Polish, was subsequently edited, and my own voice largely excised, though its sonic traces, such as fragmentary exclamations, sighs, laughter, tail-ends of words were intentionally retained. These editing choices emphasized Irena's powerful abilities as a storyteller, and in turn underlined contrasts in tone and emotional resonance as each object was discussed. Through drawing attention to cuts, I wished to evoke my experience of relational clumsiness when confronted with Irena's resilience, shadowed by trauma. The testimony's translation I integrated into the macro-lens video footage, as mid-titles appearing centre-screen, foregrounding the translation process through a series of textual and typographical conventions that evoked a poetic form beyond quotidian conversation. They were designed to flow in meaning-aligned rhythmic synchronicity with Irena's narration. Thus, I developed my own role: the translator of both verbal and non-verbal aspects of my mother's experience. I could try to create a bridge between her and the viewer.

As we watched the project's first iteration with an audience, the effect of hearing Irena's amplified voice proved challenging for her to process, equally, witnessing my aesthetic choices in company knocked me into a state of groundlessness. These sensations resulted in a delayed, visceral shock, taking us both unawares. It is important to acknowledge that making work of this nature, given its auto/biographical, auto-ethnographic dimension, is unsettling. Surviving Objects concerns an intimate legacy, a departure from privacy, which both invokes a position 
of vulnerability and reaches out for its antidote - courage. In Stuart Hall's formulation, representation involves work (Hall 1997), and much of that labour in practice-led research that takes material such as this as its subject must embrace distress. Any tendency to exile awareness of these painful complexities from discussion of representational choices - as though it were somehow beyond the work's critical dimension and outside politics - is a mistake, precisely because it compounds the pathology instigated by historical acts of violence, silencing and humiliation. This problem is sharpened when the victim of such acts was at the time a child, and now takes her place as the work's subject.

How creative practice negotiates these issues in relation to its audience is a connected, though different issue. All iterations of Surviving Objects have experimented with audience positioning, which has produced varied types of proxemic and kinesic engagement and modes of witnessing. Though in the second iteration (2014) the audience was seated end-on, facing the performance/exhibition space, and was not manifestly invited to touch the objects, they repeatedly entered the space at the performance's close, picking up and holding them for some considerable time, while the object handlers looked on. As the objects were positioned on the floor, this meant crouching down to their level. In the third iteration (2016), I displayed the objects on plinths, experimenting with gallery aesthetics, and singly positioned gallery stools around the studio perimeter. Visitors gravitated towards the stools, where they sat viewing objects and the projection. In the fourth iteration (2018), personal technology in a constrained space meant that visitors were proxemically close to both the objects arranged in the bunker 'living room' and each other. This rendered physical engagement with the objects themselves highly unlikely, though each person's navigation through the digital material, and experience of Irena's storytelling, was unique.

Surviving Objects is driven by a desire to understand the role played by Bwana MKubwa, and by a refugee camp, in our family life. This desire to understand stimulates more archive as the project continues to change its shape and mode of engagement. It represents migration and integration as iterative, dynamic and open-ended, qualities filtered through the inevitable implications of my mother's life stage. Surviving Objects takes as its ethical premise a conviction that Irena must speak about Bwana MKubwa now, before it is too late, and that I must facilitate this. Given the project's form, that 'now' can be repeatedly recalled. For my mother, Bwana MKubwa is a place of refuge, experienced as safe, as warm, and as home. 'It is where I want to go next', she tells me.

I would like to show Surviving Objects in a formal museum space, looped and unconstrained by a specific duration, embedding the invitation for visitors to move through and 
revisit the exhibition and inviting reflection on its political dimensions in contexts reserved explicitly for experiencing material culture. The entry of this personal archive into a formal host museum would be a transformative act. The project conceptualizes its surviving objects as heirlooms, as tangible family heritage, drawing on archaeologist Roberta Gilchrist's work (see Gilchrist 2013). She suggests that the process of heirlooms' transition from a private domestic space into a space purposed for public viewing transforms their biographical status to encompass connotations of sacredness. Through my aesthetic choices for Surviving Objects I aim to invoke the notion of inviolability, reflecting my desire to affirm the human rights of an individual who experienced their violation. The stories Irena chooses to tell me emphasize strategies for recuperation and empowerment discovered in the refugee camp in Bwana MKubwa. Her choice to recount them in Polish, her mother tongue and mine, though both of us speak fluent English, is clearly of significance within the context of the UK-based migration debates signalled in the introduction to this paper.

In an article that investigates, in the context of the 'migrant crisis', the Italian media's contribution to persistent reproductions of stereotyped and sensationalist representations of migrants, Pierluigi Musarò and Paula Parmiggiani have discussed the need for alternative approaches and a fundamental shift in how we communicate about migration (Musarò and Parmiggiani 2017). In response to this call, which I consider resonant in the context of a preBrexit UK, I aim to continue Surviving Objects, developing my capacity for listening and attentiveness, seeking appropriate channels for communicating how migration continues even after journeys have ended, asking how, where and to whom Irena's humorous resilience, her creative spirit, can be responsibly mediated.

\section{All Roads Lead to Rome}

Chris Dobrowolski's one-man, mixed-media performance All Roads Lead to Rome (2013), takes the form of a tongue-in-cheek interactive public lecture. As in Surviving Objects, Dobrowolski draws on a family archive in order to create his performance, but he also has a far broader and more playful conceptualisation of what constitutes that archive. Not only do his object sculptures feature within the performance frame, but he also harnesses a range of materials from different periods in his own life, including toys and photographs from his childhood, to feature in a hybrid PowerPoint presentation/video forming an integral part of the show. Armed with over-sized pointer and PowerPoint clicker, Dobrowolski places himself firmly centre stage, and narratively retraces for the audience's delectation and delight his father's experiences in the Polish Army as part of World War II Italian Campaign. He achieves 
this through the interpretative lens of a journey made after his father's death in order to create the project. The fact that he made this journey, accompanied by his Italian-speaking girlfriend Priscilla, lends All Roads Lead to Rome its expansive tone and durational frame, emphasising the artist's commitment to his research and his willingness to explore the limits of empathic identification with his father's migratory experiences. Dobrowolski entertains us with the story of how Arts Council England funded him to do up his old family car, a rickety Triumph Herald Estate, which took its own happy old time in getting from Chris's childhood home in Braintree, via Turin, to Rome and through a visit to Monte Cassino, where a battle significant to the Italian Campaign was fought in 1944. This is an event and place that Dobrowolski seeks to understand and touch through his performance, but unlike Surviving Objects' somewhat nostalgic, introverted approach to recalling Bwana MKubwa, the artist devises the most arduous and protracted way of travelling to Italy, both as a way of publicly admonishing himself for not having experienced the many horrors and futilities of the battles his father Kazimierz participated in, but also as an ironic commentary on the ways in which the politics of fascism and communism intersected in his migration journey and shaped Chris's own life. Before joining the Polish army, his father had been deported from Poland to Siberia at the start of the war.

Through the strategic use of both slapstick humour and irony, Dobrowolski establishes his own position as a deliberately hapless artist trying to understand, together with the audience, the complexities of his father's journey - and of the entire war, and Cold War, no less regularly evoking his father's Polish-accented voice and expletive-prone presence through a shift in register in his own performance. Whereas hushed tones tend to prevail in Surviving Objects, Dobrowolski reaches out in the most direct terms to his end-on audience, addressing them, inviting their responses, and enlisting their support through humour. Not every aspect of this journey will make sense, he suggests, but we will enjoy its absurdities together. About halfway through the show, the spectator is suddenly confronted with a vivid projected photographic image of his father, showing him in Siberia following his deportation there at the start of the war, and pictured with a group of labourers in a forest. There follows Dobrowolski's indignant evocation, accompanied by colour family photographs, of how every illness and crisis in his own childhood seemed to pale into insignificance compared with what the young boy knew that his father endured there. This type of reflexive framing, and a self-conscious weaving of visual patterns and mnemonic connections in order to create temporal layering, is vital to the narrative structure deployed by Dobrowolski and its elements of surprise. All Roads Lead to Rome deploys aesthetic conventions aimed at critically framing those acts of 
remembering, and of memorialization, that form their core. This includes, for example, Dobrowolski's cross-cutting between different types and styles of projected stills and videobased imagery, hailing from different periods in his own and his father's life, and including maps, in order to mirror the narrative's governing rhythm, one that is defined by the chuntering progress of the Triumph Herald Estate across Europe and up the mountain to the military cemetery in Monte Cassino. Its progress down the mountain is, incidentally, infinitely smoother, though Dobrowolski does find it difficult to keep the car door closed as the vehicle descends the winding road. The viewer is privileged to see, live, one of the Triumph's car seats during the performance. This is all that remains of the vehicle, which was set alight while parked in a street when Dobrowolski was performing at a festival.

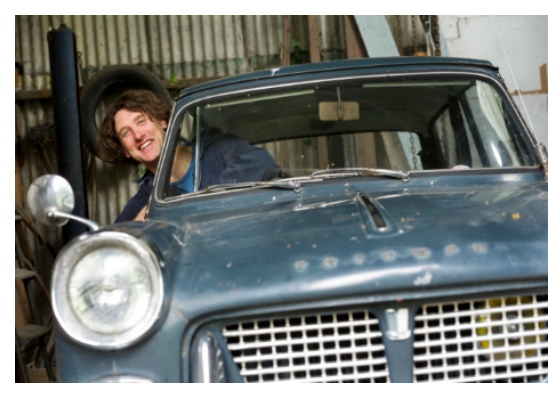

Figure 4: Chris Dobrowolski poses for a publicity photograph in his family's Triumph Herald Estate. Copyright Chris Dobrowolski

An integral aspect of Dobrowolski's showing of work alongside POWG colleagues has been his concurrent exhibition of mechanical object sculptures, ingenious compilations of items recovered from, amongst other venues, his father's old shed; fridges, record players and the like. These, he adapts to act in enhanced, unexpected ways, and they usually need a power source. His diorama Siberia, which seats one (who can be surreptitiously viewed from outside by others), is a wooden latrine structure, at once reminiscent of a large upturned coffin, a compressed shed, and a medieval instrument of torture. Once you are inside, you can sit on the 'loo', but your head is constrained by a wooden circular structure that reflects your wooden toilet seat. Around this - around your head - moves a toy train, to the crackling strains of a Polish folksong, Ej! Przeleciat Ptaszek, or, The Little Bird Has Flown. Siberia is a work that further develops for the viewer of Dobrowolski's one-man-show the resonances of that black and white photograph of Kazimierz Dobrowolski in Siberia. Chris's expansive conceptualisation of what constitutes his personal archive allows him to playfully, powerfully wrestle with how legacies of Soviet politics are shaping his life and work. His vivid, direct way 
of addressing his audiences and the driving momentum of his storytelling powerfully evokes his relationship with his father. In my experience audiences frequently end the show with the sense of having bonded, and are reluctant to leave the space. They approach Dobrowolski in order to speak with him, quite often about cars. Through encouraging conversation, Dobrowolski's performance can be a moving act of advocacy on behalf of his father's, the migrant's, indomitable spirit.

\section{Bark \& Butterflies}

Echoing Dobrowolski's emphasis on travel, in producing his audio-visual installation Bark \& Butterflies in 2013 Adrian Palka retraced his deceased father's World War II deportation journey to a now derelict and overgrown labour camp in Siberia as part of a research field trip. In contrast to Dobrowolski, Palka returned to the place where his father's deportation journey first began, taking this as his point of departure, and travelling from there to Siberia. In order to achieve this, he drew on a personal archive, namely his grandfather's and father's shared journal, which had been co-written in Polish when Jan Palka was still in his teens, and which recorded their wartime journeys and experiences. In the labour camp, when Adrian's grandfather Zygmunt died following arrest by the NKVD in 1941, Jan continued for a time to write in the diary, now completely alone, until he was released in 1942

Adrian's intention was that this journeying approach to research might enable him to acquire a new form of embodied knowledge about his grandfather's and father's writing, which includes reference to the extreme state of an exile's existence. Adrian reports how, when he was a child, and refused to eat, his father would tell him that he had once had to survive on bark and butterflies, something that acquired new connotations when Palka witnessed the phenomenon of vast numbers of butterflies flocking together in the Siberian taiga.

My use of the term 'exile' in relation to Jan Palka here is significant. Unlike my mother Irena, for whom the term 'refugee' was not only a statement of fact but also an affirmation of her experience, Adrian has revealed that Jan Palka actively eschewed the term. The potential dangers of returning to Poland following the Second World War for those who had been forcibly displaced meant that many chose to settle or remain temporarily abroad. If they had joined a Polish Division, for example, and seen active service, like my maternal grandfather, Dobrowolski's father and Jan Palka, they were frequently offered a range of re-settlement possibilities, the UK being one of them. The idea of being in exile may have chimed with this position, and foregrounded the fact of being unable to safely return to a free and democratically 
governed home country rather than reliance on the beneficence of the host country.

The emphasis in Palka's installation is on reconstruction. It takes the form of a tall, narrow wooden hut that viewers enter by pulling aside a black curtain, which suggests one of its identities as a viewing 'booth'. Inside, one can stand in close proximity to no more than two or three other viewers in order to watch a film projection and listen to an audio-recorded, simultaneously audio-translated reading of a lyrical extract from Jan Palka's diary. The installation incorporates birch bark that Palka collected on the research journey that re-traced his father's steps in Siberia (Palka 2018).

I first encountered the installation when it was set up outdoors, on a windy day, on a neatly clipped lawn outside a vast metal and glass building at Coventry University. Its anachronistic appearance, in terms of building materials, scale and function, conjured associations with Dr. Who's Tardis. I began to think of it as a compact time travelling device or a portal to another world, an idea that connects with the romantic impulse driving this project, a desire to allow the viewer, through Palka's creative work, to 'touch' and enter a different place and register of existence. At the same time, its design and association with paternity resonate with stereotypical notions of 'dad's old shed', a private, secluded and functional space, to which one can withdraw, and where in this case, one will find fleeting traces of an absent father. Given these conventions of engagement, the sense of absence and grief is palpable; this is a portal, but it is also simply a shed, its limitations as both a shrine and a mnemonic resource are clearly drawn through Palka's selective approach to both building materials and storytelling choices. In this respect, in contrast to the uplifting and ebullient tone of Dobrowolski's All Roads Lead to Rome, Palka's project has more in common with Surviving Objects. Loss and nostalgia pervade these two pieces in ways that emphasise the emotional challenges of reconstructing difficult journeys of exile.

Outside the hut, the smell of the wood it is constructed from is pervasive. This olfactory invitation to move down the path of sensory immersion, and through it towards 'transportation', in Puriņš's formulation (discussed below) 'across the years,' is also extended within the indoor environment (Puriņš, 2016). There, a well-used and open 1940s style brown leather suitcase with a partially attached handle - not in fact belonging to Palka's father, though this is how one may read it - stands filled with smaller logs and birch bark on a raised structure. This small collection of wood forms the surface for a video projection from a projector suspended directly above from the hut's ceiling. Should the viewer wish to touch or pick up the logs or bark in the suitcase to, for example, smell them, her mobile hands can then become part of that multidimensional and organic projection surface, implicating her in the installation's textured 
design.

The visual style of the short, looped film evokes a kind of magical realism that has aesthetic resonances with Elina Kalniņa's visual approach in Esi Pats! or Be Yourself!, a web-based archiving project about the Soviet deportations from Latvia (Kalnina, 2015). Its incorporation of archival materials, in this case a mediated, static, sepia photograph of Palka's father as a young man, is framed and animated through its formation of one layer within a colourenhanced montage of visual effects. What the wooden hut/booth alone cannot articulate through its propensity towards decay and relentless consumption by woodworm, is addressed through the fluid, mobile effect of what at first seems to be an animated drawing playing delicately across the logs. This is produced by the video montage incorporating moving images of the flight of butterflies, footage taken on the Siberian field trip, which appear to flit across the bark onto which they are projected, or, for example, across the viewer's hands if they happen to handle the logs. This approach reflects in its tone on the simultaneously played audio material, which has an incantational quality. It comprises an actor reading a poem written by Jan, dedicated to the taiga in Polish, and Palka's whispered translation of this into English, sonically interleaving it (Palka 2018: 102). Importantly, Palka prefers to show this installation in a gallery setting, and one of its more recent iterations took place in his hometown, Leeds' City Museum (2018).

In contrast to Surviving Objects and All Roads Lead to Rome, Palka's creation of an intimate, sparse, sensory environment where visitors can temporarily linger serves to highlight our fleeting encounter with Jan's creative writing, produced as a result of, and in spite of, the most extreme circumstances. The archival materials that Palka works with are strikingly different from those that underpin the two projects described above, taking the form of written testimony. The fact that Jan's diary entries continued after Zygmunt's ceased further embeds the notion of intergenerational transmission within the broader project. Through its layering of imagery, sound and journeys, Bark \& Butterflies captures both the notion of mobility, and of being moved to continue.

\section{Peeling Onions with Granny}

The short film Peeling Onions with Granny is key to the work of the POWG collective, and inspired our name. Looped during its installation, and thus underpinned by aesthetics of repetition, it was created specifically for the first POWG collaborative event in 2016. As such, 
it distils and advances many of the themes that have been raised in relation to the three projects discussed so far, particularly concerning intergenerational transmission of forced displacement legacies, and the animation and opening out of personal archives. Its creator, Simon Purinšs, an artist born in the United Kingdom whose father was from Latvia, based the script around an imagined dialogue between his grandmother, Marija, who was deported from Latvia to Siberia, and one of his two UK-born daughters. Grandmother Marija died in 1987, aged 100. The impact of the 1941 and 1949 Soviet deportations of Latvian citizens is still in the process of being researched and understood. It has acquired additional significance as Latvia's relationship with Russia, and Russia's relationship with all the Baltic States (as well as other countries across the globe) is once again diplomatically and militarily strained. ${ }^{3}$

Puriņ̌s wrote the film script for Peeling Onions with Granny in English. It is lyrical and incantational - a 'call and response' piece - thus signalling the fact that this repeated conversation never took place. Purinšs's presence is arguably not emphasised within the work. However, for the viewer, questions about the filmmaker's relationship to the speakers remains enticing throughout.

One of Purinsš's daughters, Iza, who was eighteen at the time, was recorded voicing her part of the script in her native English accent, and his 90-year-old friend Zigrīda Daškevica was recorded delivering her great-grandmother's part in her Latvian-accented English. Zigrīda's hands are also the visual focus for the film that, through its 'de-saturated colour' tones, emphasises their lined, textured qualities. They represent Marija's hands; Zigrīda's task is to embody Marija. We see these hands teasing loose and removing onion skins and layers in a repeated cycle of movement, without using a knife, until they reach the onion's heart. We also watch intersecting episodes showing Iza's hands. Following a call and response section, where the women address each other, the once separate images of their hands are visually overlaid, as are their voices. These aesthetic choices, embedded within the film's cyclical form, symbolically align the film itself with the shape and structure of an onion. The film takes as its stimulus the only photograph of his grandmother in Puriņš's possession (see Figure 2) part of which appears twice in the film, during the 'overlaying' sections, and enables us to situate the likely owner of the older pair of hands. In the photograph, she is shown surrounded by suspended ropes of bunched onions, seemingly waiting. This image was taken after the war, by a family member in Latvia, whence Purinšs's grandmother had managed to return by

\footnotetext{
${ }^{3}$ In relation to this context, the work of Melānija Vanaga, who died in 1997, is key. Vanaga's book Suddenly a Criminal: Sixteen Years in Siberia, originally published in 1991, is a seminal Latvian memoir of involuntary exile.
} 
shrewdly seizing a rare opportunity to re-negotiate her identity when questioned by an official: she happened to share her surname with, though was not related to, a Soviet town luminary whose statue stood in the market square. Ironically, this became her key to early release from exile. The significance of onions for deportation narratives, as an unpalatable foodstuff eaten by forced labourers because nothing else was available, reminiscent of Jan Palka's reference to eating birch bark and butterflies, is implicit in Purinsšs film. Additional trans-cultural associations that accrue around this pungent vegetable, suggestive of involuntary weeping and unending processes of stripping away, are fundamental to how Purinšs's reiterative reflections on this family legacy shape the film; Puriņš never met, and can never meet, his grandmother. Neither can his daughter. The circular motion of the dialogue and the looped film tirelessly return us to the same point of departure. Although the dialogue invokes the need for celebration, once the heart of the onion is reached, the task of peeling must begin again. The episodes that include hands peeling onions are interspersed with footage of partially glimpsed landscape filmed at night through thick wooden slats from within a train carriage, referencing a perpetual, Sisyphean deportation journey. The temporal distance between the two women, and also their fictionalized journey towards (and away from) each other, 'across the years', never abates. The filmmaker can animate his family archive, his way of collaborating in the act of onion peeling. He can bring the photograph to life, perhaps imagining what Marija and Iza might do next. Yet through incorporation of his daughter's voice in the film he chiefly dramatises the conveyance of Marija's legacy to her, and Iza's whispered curiosity about that legacy. He also implies, through the film's reiterative qualities, that a similar deportation journey could be experienced by this young woman, and by extension is being experienced now by others of her generation.

Through its emphasis on reiteration, Purinššs film embeds the tension between two impulses arguably shared, to varying degrees, by all the POWG artists considered here. Firstly, an impulse to return, and then return again, to difficult legacies of forced displacement, to submit once again to the archive with its unstable and receding centre. Secondly, an impulse to transform this inclination to return, and then return again, into a fertile point of departure, a possible opening out of the archive that gives it room to breathe, however acrid the atmosphere, and to reach beyond itself.

\section{Conclusion}

As mentioned earlier, Roberta Gilchrist's work on heirlooms has resonance for me in relation to the POWG artists' engagement with archival materials and objects. She notes that 
archaeologists have been 'instinctively wary of heirlooms.' They are regarded as 'taphonomic or methodological problems' and are often conceived as residual objects: 'old things excavated from stratified contexts possess the power to contaminate site chronologies' (Gilchrist 2013: 170, original emphasis). I find it productive to think of my mother's small object collection from across the globe, and those fragmented stories that embrace them, as heirlooms. When I start to work with them, methodological problems invariably arise. Equivalent materials belonging to others - equivalent stories - are visible in temporal strata beneath, around and above them, including those migration and displacement stories that repeatedly recur across generations of my own family. My excavation of these, sometimes so challenging when conducted in solitude, feels infinitely more possible when carried out in company. In resisting the degradation of these heirlooms, I hope to have repurposed them, and I trust that any power they have to 'contaminate' sites of anti-immigrant feeling retains its potency.

The case studies discussed in this chapter are aesthetic and ethical sites that represent historical journeys of migrants, refugees and exiles and traumatic experiences of displacement. However, when considered as relational artworks, they also foster new understandings of migrancy today, illuminating in particular the role that post-generation practitioners can play in communicating their own experiences of living and working with these difficult legacies.

\section{References}

Akthar, Zahra and Lovell, Andrew (2019), 'Art therapy with refugee children: a qualitative study explored through the lens of art therapists and their experiences', International Journal of Art Therapy, 24:3, pp. 139-148.

Anon. (2017), The Saga of the Volsungs with The Saga of Ragnar Lothbrok, (trans. J. Crawford), Indiana: Hackett.

Bikont, Anna (2015), The Crime and the Silence: Confronting the Massacre of Jews in Wartime Jedwabne, (trans. A. Valles), York: Farrar, Straus and Giroux.

Derrida, Jacques (1996) Archive Fever: A Freudian Impression, (trans. E. Prenowitz), Chicago: University of Chicago Press.

Duffy, Carol Ann (1993), 'Valentine', Scottish Poetry Library, https://www.scottishpoetrylibrary.org.uk/poem/valentine/. Accessed 15 May 2019.

Cox, Emma \& Wake, Caroline (2018), 'Envisioning Asylum/Engendering Crisis: or, performance and forced migration 10 years on', Research in Drama Education: The Journal of Applied Theatre and Performance, special issue: 'Envisioning Asylum/Engendering crisis', 
23:2, pp. 137-147.

Daddario, Will, Dhamankar, Janhavi, Loayza, Milton, McKenzie, Jon, Meerzon, Yana, Nauha, Tero, Schmidt, Theron \& Stojnić, Aneta (2018), 'What is Refugee?' Performance Philosophy 4:1, pp. 206-233.

Davies, Norman (2015), Trail of Hope: The Anders Army, An Odyssey Across Three Continents, London: Osprey.

Dobrowolski, Chris (dir.) (2016), All Roads Lead to Rome, Chris Dobrowolski, Minghella Studios, University of Reading, 14 December.

Grass, Günter (2007), Peeling the Onion, (trans. M. H. Heim), London: Random House.

Gilchrist, Roberta (2013), 'The Materiality of Medieval Heirlooms: From Sacred to Biographical Objects', in H. P. Hahan and H. Weiss (eds.) Mobility, meaning and the transformations of things: shifting contexts of material culture through time and space, Oxford: Oxbow, pp. 170-182.

Hall, Stuart (1997). Representation: Cultural Representations and Signifying Practice, Thousand Oaks: Sage.

Hirsch, Afua (2019), 'The Channel migrant 'crisis' is really a tale of British hypocrisy', The Guardian, 3 January 2019, https://www.theguardian.com/commentisfree/2019/jan/03/britainmigrant-crisis-sajid-javid-hypocrisy. Accessed 15 May 2019.

Hirsch, Marianne (2012), The Generation of Post-Memory: Writing and Visual Culture after the Holocaust, Columbia: Columbia University Press.

Hirsch, Marianne and Nancy K. Miller (eds.) (2011) Rites of Return: Diaspora Poetics and the Politics of Memory, New York: Columbia University Press.

Hirsch, Marianne, 'Author Interview', Columbia University Press, https://cup.columbia.edu/author-interviews/hirsch-generation-postmemory. Accessed 1 January 2019.

Ibsen, Henrik (1990), Peer Gynt, (trans. Kenneth McLiesh), London: Nick Hern. Kalniņa, Elina (2015), 'Esi Pats!', http://www.esipats.lv/. Accessed 2 January 2019.

Kwock Kim, Suji (2003), ‘Monologue for an Onion', poets.org, https://poets.org/poem/monologue-onion. Accessed 3 May 2019.

Marschall, Anika (2018), 'What can theatre do about the refugee crisis? Enacting commitment and navigating complicity in performative interventions', Research in Drama Education: The Journal of Applied Theatre and Performance, special issue: 'Envisioning Asylum/Engendering crisis', 23:2, pp. 148-166.

Murjas, Teresa (dir.) (2016), Surviving Objects, Teresa Murjas, Minghella Studios, University 
of Reading, 14 December.

Musarò, Pierluigi and Parmiggiani, Paola (2017), 'Beyond black and white: the role of media in portraying and policing migration and asylum in Italy', International Review of Sociology, 27:2, pp. 241-260.

O'Neill, Maggie (2008), 'Transnational Refugees: The Transformative Role of Art?'. Forum Qualitative Sozialforschung / Forum: Qualitative Social Research, 9(2), Art. 59, http://nbnresolving.de/urn:nbn:de:0114-fqs0802590. Accessed 24 July 2019.

Palka, Adrian (2017), Bark and Butterflies, installation, Coventry University, 23 June.

Palka, Adrian (2018), 'Bark and Butterflies: Redeeming the Past - Digital Interventions into Post-Memory' in S. Whatley, R. Cisneros and A. Sabiescu (eds.) Digital Echoes: Spaces for Intangible and Performance-based Cultural Heritage, Palgrave Macmillan, Cham, pp. 83-106. Puriņš, Simon (2016), Peeling Onions with Granny, installation, Minghella Studios, University of Reading, 14 December.

Varanga, Melānija (2015), Suddenly a Criminal: Sixteen Years in Siberia (trans. M. VoitkusLukins), Friesen Press.

Wake, Caroline (2013), 'The Accident and the Account: Towards a Taxonomy of Spectatorial Witness in Theatre and Performance Studies', in B. Trezise and C. Wake (eds.) Visions and Revisions: Performance, Memory, Trauma, Copenhagen: Museum Tusculanum Press, pp. 3356.

\section{CONTRIBUTOR DETAILS}

Teresa Murjas is a Professor in the Department of Film, Theatre \& Television at the University of Reading, UK. Her research interests lie in translation for performance; conflict representation on stage and screen; memory, materiality and the archive in performance. She creates work in a range of media, including live performance, video and online, always working collaboratively, and frequently partnering with non-academic organisations, such as museums, galleries and community-based venues. For an example of her web-based work, please see https://www.war-child-archive.com. Alongside Peeling Onions with Granny, Teresa has also set up the performance company Around the Well at the University of Reading. Around the Well is comprised of professional interpreters from a range of backgrounds and the company's devised performance lecture Between shares stories of their experiences of working with migrants to the UK in public service settings. 


\section{CONTACT}

Department of Film, Theatre \& Television, Minghella Studios, University of Reading, Whiteknights Campus, Shinfield Road, Reading RG6 6BT.

t.s.murjas@reading.ac.uk 